\title{
The Effect of Compensation and Work Discipline on Teacher Performance in Semendawai Barat Elementary School
}

\author{
Kamal $^{1 *}$, Bukman Lian ${ }^{1}$, Alhadi Yan Putra ${ }^{1}$ \\ ${ }^{1}$ Universitas PGRI Palembang \\ *Corresponding author. Email: kamalmandala89@gmail.com
}

\begin{abstract}
The aim of this study was to see how job discipline and compensation affected elementary school teacher efficiency. in Semendawai Barat sub district. This research was conducted in Elementary Schools on Suka Negeri of Semendawai barat sub-district. This research was conducted from June to September 2020. The data collection techniques used in this study included questionnaires, observation and documentation. respondents in this study were 60 teachers. The data analysis method used quantitative analysis, using the SPSS 21 application. The correlation analysis, $t$ test, and F test were used in the analysis. The results of the questionnaire data analysis showed that job discipline had an impact on the output of public elementary school teachers in Semendawai Barat, which was agreed. Compensation has an impact on the performance of public elementary school teachers in Semendawai Barat, according to the findings. The $\mathrm{F}$ value has been determined to be 83,734 with a sig level of 0,000 . The hypothesis that job discipline and pay have an impact on the output of elementary school teachers in Semendawai barat is acknowledged because the sig value is less than 0.05 . This shows that about $81.9 \%$ of the variations that occur in variable $\mathrm{Y}$ can be explained by variations in variables $\mathrm{X} 1$ and X2. There is an effect of Work Discipline and Compensation together on the performance of Elementary School teachers in Semendawai barat.
\end{abstract}

Keywords: Work Discipline, Compensation, Performance

\section{INTRODUCTION}

A teacher is a qualified educator who has the quality and great responsibility towards the school. In educational institutions, achieving an objective is based not only on modern equipment, facilities, and infrastructure, but also on the people who perform the work. Since the performance of a company's employees has such a significant impact on its progress, any educational institution would strive to enhance employee performance in the hopes of achieving the company's objectives. Nowadays, the development of the world of work is marked by the increasing competition and the narrowing of available jobs. This is the main cause of the increasing unemployment rate that Indonesia is currently experiencing.

Schools as formal educational institutions play an important portion in improving the quality of education through the learning process to support the smooth running of development in Indonesia as a whole. Learning is the main activity of schools as a form of education service for the community. Schools are given the freedom to choose strategies, methods, and learning techniques that are in accordance with the characteristics of subjects, students, teachers, and the real conditions of the resources available in the school. In general, studentcentered learning methods are better able to empower student learning [1]

Based on the descriptive analysis of the compensation received by teachers at senior high school 6 Banda Aceh in the good category, and from the results of the research, the direct compensation and indirect compensation have a good effect on teacher performance. With the direct compensation received by senior high school 6 Banda Aceh teachers, such as receiving a complete salary on the same date and regularly every month, the teacher's performance has also increased. In addition, by continuing to receive a full salary even though during that month there was a time when the teacher was unable to attend, this would increase the teacher's performance. Work discipline is the act of a teacher to comply with mutually agreed upon rules. This action if done correctly and continuously will become a habit that is embedded in teacher behavior and will help achieve the teacher performance expected by the institutions [2]. Teacher discipline will always have a positive impact on academic daily life at school. So that 
time discipline, work has been done, it will create a harmonious work climate

Based on the descriptive analysis of the work discipline of State Elementary School teachers in West Semendawai District in the good category. This is evident from the results of research, where teachers who enter class and leave school on time and are able to complete subject matter in accordance with the Learning Implementation Plan, their performance also increases (Researcher survey results).

Elementary School in Semendawai Barat District is an government institution that regulates issues related to education. The success of the Elementary Schools in Semendawai Barat Subdistrict in carrying out the above tasks and functions cannot be separated from the performance produced by the teachers in carrying out their duties. Good performance will certainly result in the quality and quantity of the work results towards the goals of the institution / organization. Good performance can only be achieved if it is supported by quality human resources who are professional, creative, motivated, dedicated and loyal. So that the Elementary Schools in Semendawai Barat District which have main tasks and functions must be carried out properly in accordance with what has been programmed by the government in the area of regional income. Improving teacher performance will probably be possible if the discipline of teachers in their work is high. Teacher work discipline is needed in an institution because the goals of the institution depend on how teachers work. Because according to temporary observations, the performance of teachers, especially Elementary Schools in Semendawai Barat District, now still needs to be improved, where teachers often neglect their duties in institutions for other tasks so that if this situation is not looking for problems, the performance of the staff will continue to decline and organizational goals will not be achieved properly (Researcher survey results).

Currently, the Elementary Schools in Semendawai Barat Subdistrict are actively making improvements regarding the problem of teacher ability in carrying out their duties, especially those related to teacher affairs which will indirectly affect the performance of Elementary School teachers in Semendawai Barat District. The performance of Elementary School teachers in Semendawai Barat Subdistrict today is considered to be not optimal, such as the attendance and punctuality of teachers at work, often not according to work schedules or hours, teachers often leave the office during working hours or arrive late, as well as the ability of teachers at work has not achieved maximum results, the attitude of supporting the organization is very lacking because many teachers work as is as well as planning and coordination at work is not there so that many assignments are not completed on time or are completed suddenly so that they are completed in a hurry (Researcher survey results) .
In addition to the discipline of teachers that the leadership must pay attention to, perhaps an increase in compensation can also increase the enthusiasm of teachers at work. This compensation is given because it is suspected that these Elementary School teachers in Semendawai Barat District cannot work properly because the income they receive is felt to be still lacking. so that there are still teachers who are looking for extras outside the office during working hours.

Improved compensation for teachers expected to further motivate teachers to improve their performance, this is done because of the assumption that the income of teachers still needed to be improved so that the need for additional income excluding salaries. The compensation provided by the Elementary School in Semendawai Barat District is in the form of financial and non-financial compensation. Financial compensation such as additional incentives, wages, bonuses for their work success. Meanwhile, the non-financial compensation provided includes working facilities as well as rewards for their services to institutions and also the ease of continuing education for outstanding teachers. This increase in compensation is very important because with sufficient income, of course, teachers will focus on their work and will not seek additional work outside of working hours and this makes teacher performance less than optimal.

From the description above, the authors are interested in examining about "masalah Pengaruh Displin kerja dan Kompensasi terhadap kinerja guru Sekolah Dasar Negeri di Kecamatan Semendawai Barat”.

\section{LITERATURE REVIEW}

\section{Performance}

Performance appraisal is a process for measuring employee performance based on predetermined regulations, by comparing targets (results of work) with job description requirements, namely Job standards that have been developed for a particular period of time [4]. Both qualitative and quantitative job standards can be developed. Performance is the result of a person's work which is based on the improvement of these activities in accordance with the responsibilities and expected results [5]. Performance is an action and not an event because the success of doing work is largely determined by one's performance. Performance is a series of individual behaviors and activities in accordance with organizational expectations or goals. This performance is related to effort, but performance must be measured in relation to the results achieved, this performance is an action of a process that involves various components of the activity because performance is not only seen as the result achieved but the process of achieving these results also greatly supports the achievement of organizational goals.

From the theory that has been stated above, performance can be synthesized as anything that is 
achieved and created in the form of goods or services by an individual or group of people based on their talents, abilities, expertise, and experience within a specific time frame and in a specific size range.

\section{Work Dicipline}

Discipline is a word that we often hear in everyday life, usually referring to someone's obedience or obedience to a rule. For more details, here are some definitions of discipline from several experts. Discipline is an orderly state in which followers happily submit to the teachings of their leaders [3]. Discipline or order is defined as the willingness to comply with provisions in the form of regulations which explicitly need to include sanctions that will be received in the event of a violation of these provisions [6]. Discipline is a condition that is created and formed through a process of a series of behaviors that show the values of obedience, obedience, loyalty, tranquility, order, and order [7]. In relation to work discipline. Work discipline is an attitude of respect, respect, obedience and obedience to the applicable regulations, both written and unwritten and able to carry it out and not evade receiving sanctions if he violates duties and authority given to him [8].

Concludes that work discipline is an important function of human resource management and is the key to the realization of goals, because without work discipline, it is difficult to achieve maximum goals [9]. Work discipline is a desire and awareness to obey organizational rules and social norms. So, discipline can be considered as a work process that leads to order and self-control.

From some of the definitions stated above, it appears that discipline is basically an act of management to encourage members of the organization to comply with the various rules and regulations that apply in an organization, which includes: (1) the existence of an order or provisions; (2) the obedience of followers; and (3) there are sanctions for violators.

\section{Compensasion}

Compensation or incentives are one way for a company or organization to encourage people to do their jobs properly and with a full sense of responsibility. Intensive also means paying wages for work performance that has been done by an employee, which of course differs according to the responsibilities and scope of his duties. Incentives are often interpreted as a form of payment that is linked to performance, as a share of benefits for employees due to increased productivity. This system is another form of direct compensation other than salaries and wages which is permanent compensation, which is called performance-based compensation [10]

Compensation is one of the most important and fundamental personnel management functions in an organization [11]. Compensation can be said to be a form of function which is formulated as a form of remuneration that is appropriate and adequate to personnel for their contribution to organizational goals. Compensation can be used to assist organizations in recruiting, retaining, and motivating employees to work more actively [12]. In this regard, the compensation referred to can be in the form of payment and other benefits such as sick leave, vacation and health insurance.

From the description above it can be synthesized that compensation is "everything that employees receive in return for their work". Compensation itself can be divided into two types, namely financial compensation and non-financial compensation.

\section{METHODS}

The research was conducted at Elementary Schools in Semendawai Barat because the Elementary Schools in Semendawai Barat district are actively implementing teacher performance improvements in an effort to achieve institutional goals.

The authors used quantitative data in this analysis, which is described as research that requires the use of numbers from data collection to data interpretation to the presentation of the results. Quantitative research has systematic, designed, and clearly structured criteria from the beginning to the creation of the research design.

Population is "a generalization area consisting of objects or subjects that have certain quantities and characteristics that are expected by researchers to study and then draw conclusions." [13] The population that became the object of the study were all Elementary School teachers in Semendawai Barat District, totaling 16 Public Elementary Schools with 167 teachers.

The sample is part or representative of the population studied To determine the sample size if the subject is less than 100, it is better to take all of them so that the research is a population study. If the subject is bigger, it can be taken between 20-25\% [13]. Based on these opinions and to save time, cost and energy, in this study the researchers only took 4 elementary schools in Semendawai Barat District, 25\% of 16 Elementary Schools, of which 20 people were randomly assigned to test the instrument, and 40 people are used as samples to do research.

Data collection techniques used include observation, questionnaires, and documentation.

\section{RESULTS AND DISCUSSION}

Hypothesis testing is done by using correlation techniques, while the correlation techniques used are statistical analysis of correlation and determination, regression coefficient ( $\mathrm{t}$ test) and association correlation coefficient ( $F$ test), which were carried out using SPSS version 21. 
1. Hypothesis Testing of Work Discipline (X1) on Performance ( $Y$ )

Table 1. X1 Against Y

\begin{tabular}{|c|c|c|c|c|c|c|}
\hline \multicolumn{7}{|c|}{ Coefficients $^{2}$} \\
\hline \multirow{2}{*}{\multicolumn{2}{|c|}{ Model }} & \multicolumn{2}{|c|}{ Unstandardized Coefficients } & $\begin{array}{l}\text { Standardized } \\
\text { Coefficients }\end{array}$ & \multirow[b]{2}{*}{$\mathrm{T}$} & \multirow[b]{2}{*}{ Sig. } \\
\hline & & $B$ & Std. Error & Beta & & \\
\hline \multirow[t]{2}{*}{1} & (Constant) & 6.945 & 5.882 & & 1.181 & 245 \\
\hline & Disiplin kerja & .891 & .073 & .892 & 12.150 & .000 \\
\hline
\end{tabular}

From the table above, the $t$ value is 12,150 with a sig level of 0,000 . Because the sig value is less than 0.05 , the hypothesis which says there is an effect of work discipline on the performance of elementary school teachers in Semendawai Barat is accepted. This means that work discipline affects the performance of elementary school teachers in Semendawai Barat.

2. 2. Testing the Compensation Hypothesis (X2) on Performance (Y).

Table 2. X2 Against Y

\begin{tabular}{|c|c|c|c|c|c|c|}
\hline \multicolumn{7}{|c|}{ Coefficients $^{2}$} \\
\hline & & \multicolumn{2}{|c|}{ Unstandardized Coefficients } & \multirow{2}{*}{\begin{tabular}{c|}
$\begin{array}{c}\text { Standardized } \\
\text { Coefficients }\end{array}$ \\
Bets
\end{tabular}} & \multirow[b]{2}{*}{$\mathrm{T}$} & \multirow[b]{2}{*}{ Sig. } \\
\hline \multicolumn{2}{|c|}{ Model } & B & Std. Error & & & \\
\hline \multirow[t]{2}{*}{1} & (Constant) & 5.033 & 6.170 & & .816 & 420 \\
\hline & Kompens9si & .875 & .078 & .877 & 11.272 & .000 \\
\hline
\end{tabular}

From the table above, the $t$ value is 7.561 with a sig level of 0.000 . Because the sig value is less than 0.05 , the hypothesis that there is an effect of compensation on the performance of elementary school teachers in Semendawai Barat is accepted. This means that compensation affects the performance of elementary school teachers in Semendawai Barat.

3. Hypothesis Testing of Work Discipline (X1) and Compensation (X2) on Performance (Y)

Table 3. X1 and X2 Against Y

\begin{tabular}{|c|c|c|c|c|c|c|}
\hline \multicolumn{7}{|c|}{ ANOVA $^{2}$} \\
\hline \multicolumn{2}{|c|}{ Model } & Sum of Squares & Df & Mean Square & $\mathrm{F}$ & Sig. \\
\hline \multirow[t]{3}{*}{1} & Regression & 1454.600 & 2 & 727.300 & 83.734 & $.000^{\prime \prime}$ \\
\hline & \begin{tabular}{|l|} 
Residual \\
\end{tabular} & 321.375 & 37 & 8.686 & & \\
\hline & \begin{tabular}{|l|l|} 
Total \\
\end{tabular} & 1775.975 & 39 & & & \\
\hline
\end{tabular}

From the table above, the $\mathrm{F}$ value is 83,734 with a sig level of 0,000 . Because the sig value is less than 0.05 , the hypothesis that there is an influence of Work Discipline and Compensation on the Performance of Elementary School Teachers in Semendawai Barat is accepted.

\section{CONCLUSION}

Based on the results of research and discussion that has been done previously, either through descriptive statistical analysis or inferential statistical analysis, the findings in this study can be concluded as follows: The results of the test analysis are 12,150 with a sig 0,000 level. Because the sig value is less than 0.05 , the hypothesis which says there is an effect of work discipline on the performance of elementary school teachers in Semendawai Barat is accepted. R Square = 0.795 . This shows that about $79.5 \%$ of the variation that occurs in variable $\mathrm{Y}$ can be explained by variations in variable X1. There is an effect of Work Discipline on the performance of Elementary School teachers in Semendawai Barat, the results of the t test analysis are 7.561 with a sig level of 0.000 . Because the sig value is less than 0.05, the hypothesis that there is an effect of compensation on the performance of elementary school teachers in Barat Semendawai is accepted. R Square = 0.770 . This shows that about $77 \%$ of the variation that occurs in variable $\mathrm{Y}$ can be explained by variations in variable $\mathrm{X} 2$. There is an effect of compensation on the performance of elementary school teachers in Semendawai Barat, the analysis of the $F$ value is 83,734 with a sig level of 0,000 . Because the sig value is less than 0.05 , the hypothesis which says there is an influence of Work Discipline and Compensation on the Performance of Semendawai Barat Elementary School teachers is accepted. R Square $=0.819$. This shows that about $81.9 \%$ of the variations that occur in variable $\mathrm{Y}$ can be explained by variations in variables $\mathrm{X} 1$ and $\mathrm{X} 2$. There is an effect of Work Discipline and Compensation together on the performance of Elementary School teachers in Semendawai Barat.

For researchers to follow up further on the results of this study by developing independent variables that can improve the performance of elementary schools in Semendawai Barat. This needs to be done because there are still other factors that have an influence on teacher performance besides Work Discipline and Compensation because only $81.9 \%$ of Teacher Performance is determined by Work Discipline and Compensation means $28.1 \%$ is determined by factors outside of Work Discipline and Compensation. such as work allowances, division and others.

\section{REFERENCES}

[1] Triguno. (2010). Manajemen Sumber daya Manusia Gunung Agung Yogyakarta

[2] Mangkuprawira, S., \& Hubeis, A. V. (2007). Manajemen Mutu Sumber Daya Manusia Cetakan Pertama. Bogor: Ghalia Indonesia.

[3] Ametembun. (2001). Organisasi dan Motivasi, Dasar Peningkatan Produktivitas, Bumi Aksara, Cetakan Pertama, Jakarta.

[4] Agusta, S. (2013). "Pengaruh Kepemimpinan, Hubungan Kerja, dan Disiplin Kerja terhadap Kepuasan Kerja karyawan pada PT. Bintang Bali Indah Denpasar"

[5] Handoko, T. H. (2008). Manajemen Personalia dan Sumberdaya Manusia, BPFE, Yogyakarta

[6] Nawawi, H. (2005). Manajemen Sumber Daya Manusia Untuk Bisnis Yang Kompetitif, Gajah Mada Univercity Press, Cetakan Pertama, Yogjakarta.

[7] Prijodarminto, S. (2002). Dasar-Dasar Manajemen, Ghalia Indonesia, Cetakan Kelima, Jakarta.

[8] Siswanto. (2009). Manajemen Sumber Daya Manusia, BPFE Yogjakarta. 
[9] Siswoyo, H. (2011). Manajemen Sumber Daya Manusia, LPBM Global, Jakarta.

[10] As'ad. M. (2005). Psikologi Industri. Yogyakarta: Liberty.

[11] Flippo. E. B. (2008). Personnel Management, Edisi enam, Mc Graw Hill Book Company, New York

[12] Daniel M. C. (2011). Organizational Behaviour Consept Controversies and Aplication 7th.ed. San Diego: Hall International.

[13] Arikunto. S. (2010). Metode Penelitian dan Statistika.: Dunia Pustaka Jaya. Jakarta 